\title{
DIÁLOGO ENTRE TEORIAS DE DESENVOLVIMENTO ECONÔMICO PÓS SEGUNDA GUERRA MUNDIAL
}

\author{
Waldomiro Sartori Netto*, Pedro Paulo Zahluth Bastos
}

\begin{abstract}
Resumo
Com o término do segundo grande conflito armado, é estabelecida uma nova ordem mundial, havendo a categorização dos países em centrais e periféricos. Estes, por sua vez, possuem um crescimento econômico precário. E, em razão do mundo econômico desempenhar um papel tão importante na vida de uma nação, tornou-se necessário conceber uma teoria que buscasse entender a dinâmica própria dos países subdesenvolvidos e encontrasse possíveis soluções para seus problemas específicos. Neste contexto, visa-se analisar as suposições criadas a respeito. Rosenstein-Rodan cria o conceito do "big push", revelando a necessidade de um volume inicial de investimento que seja capaz de fazer com que a economia atrasada se expanda. Nurkse, por sua vez, mostra a necessidade de haver um Estado ativo, capaz de coordenar os investimentos, que devem ser realizados mutuamente.
\end{abstract}

\section{Palavras-chave:}

Desenvolvimento, Ragnar Nurkse, Paul Rosenstein-Rodan

\section{Introdução}

A teoria do desenvolvimento revela que o capitalismo não é um sistema estático, mas que compreende economias dinâmicas. Dessa forma, torna-se necessário entender a maneira como o progresso avança para os países emergentes, e quais são as dificuldades apresentadas por estes para que isso ocorra.

Assim sendo, o presente estudo tem o objetivo de avaliar a relação entre os pensamentos desenvolvimentistas formulados após 1945, especialmente os de Ragnar Nurkse e Rosenstein-Rodan, e as influências provenientes por Schumpeter.

O processo de desenvolvimento não deve buscar, inicialmente, o lucro, uma vez que deve ter como finalidade a obtenção de economias externas e lucro social, fornecendo, então, insumos mais baratos para outras empresas.

Assim, a proposta para se atingir o desenvolvimento se dá por meio de um "crescimento equilibrado", que consiste em ondas de investimento de capitais nos mais variados tipos de indústria. Portanto, no longo prazo, os efeitos dos investimentos e a ocorrência do progresso tecnológico poderiam ser percebidos em todos os setores, apresentando uma maior sinergia entre eles.

\section{Resultados e Discussão}

Após a leitura de textos considerados fundamentais para a discussão, é notável que Nurkse realiza uma síntese das principais ideias de economistas como Schumpeter e Rosenstein-Rodan, fazendo com que haja uma melhor delimitação para a Teoria do Desenvolvimento Econômico.

As principais dificuldades enfrentadas pelos países para atingirem o nível de desenvolvimento são a presença de um mercado limitado e o montante escasso de capital.

Seria função do Estado coordenar a realização de investimentos, implementando grandes empresas nos mais diversos setores, a fim de criar um mercado capaz de garantir a existência de uma demanda intersetorial e uma escala mínima de produção.

O capital se torna essencial ao processo produtivo, pois proporciona ao empreendedor os meios necessários para a viabilização da produção.
Salienta-se, portanto, a importância do aumento da poupança interna, através da compressão do nível de consumo da população e da utilização do capital estrangeiro, adquiridos por meio de empréstimos, para buscar o sustento do modelo de desenvolvimento.

Todavia, o capital externo é direcionado aos investimentos cujos projetos são bem aceitos aos prestamistas estrangeiros, enquanto os recursos internos visam realizar os planos menos populares no exterior.

\section{Conclusões}

Conclui-se, assim, que a explicação do subdesenvolvimento provém da existência de um círculo vicioso da pobreza. Dessa forma, a realização de um investimento em apenas um setor não possui força suficiente para fazer com que se origine, de forma espontânea, o processo de desenvolvimento.

Para alcançá-lo, seria preciso planejar um "crescimento equilibrado", assegurado graças a livre circulação dos fatores produtivos (mão de obra, capital e tecnologia) entre as regiões.

Esse fenômeno, além de preencher o vácuo da periferia, criaria uma rede comercial mais integrada, através do fortalecimento do comércio internacional, graças ao aumento da produtividade e à expansão do mercado interno. Com a ocorrência de investimentos internacionais, os princípios da divisão internacional do trabalho se mantêm presentes, instalando indústrias leves nas regiões subdesenvolvidas, enquanto as economias já desenvolvidas focalizam seus esforços produtivos em indústrias pesadas, capazes de abastecer todas as necessidades das áreas deprimidas.

\section{Agradecimentos}

Agradeço à minha família, ao meu orientador, à Unicamp e ao CNPq, que proporcionaram o desenvolvimento dessa pesquisa. 